\title{
Recombinant ENA-78
}

National Cancer Institute

\section{Source}

National Cancer Institute. Recombinant ENA-78. NCI Thesaurus. Code C1368.

Epithelial neutrophil activating peptide-78. A 78 amino acid member of the CXC family of chemokines, produced and secreted upon stimulation by interleukin 1 beta or tumor necrosis factor alpha. Stimulates chemotactic migration of neutrophils, monocytes, lymphocytes, and fibroblasts. 